\title{
PEMANFAATAN TANAMAN MAJA (Aegle marmelos (L.) Correa) SEBAGAI UPAYA MENINGKATKAN STAMINA PADA MASA PANDEMI COVID19 DI DESA MULYOAGUNG, DAU, MALANG
}

\author{
Sukian Wilujeng ${ }^{*}$, Sonny Kristianto ${ }^{2}$, Pramita Laksitarahmi Isrianto 3 \\ 1,2,3 Universitas Wijaya Kusuma Surabaya, Kota Surabaya, Indonesia \\ *Penulis Koresponsensi, email: sukianwilujeng_fbs@uwks.ac.id
}

\begin{abstract}
The Covid-19 pandemic has caused people to be more aware of the importance of maintaining health, in their lifestyle they prefer to return to nature. The purpose of this Penmas is to increase the body's immune/stamina to avoid disease attacks, including Covid-19. The method used is lecture, question and answer, and demonstration. What is discussed in this Public Education introduces maja fruit (Aegle marmelos (L) Correa) in terms of morphology, chemical content, potential, types of biotechnology, techniques in biotechnology, fermentation, benefits for health and packaging methods recommended by the Department of Health. The conclusion: increase participants' knowledge about the importance of knowing more deeply about the existence of maja fruit (Aegle marmelos(L)Correa). Participants know how to make hygienic health drinks made from maja fruit (Aegle marmelos(L)Correa). Increase participants' knowledge of how to packaging processed beverages using plastic bottle packaging. The next stage plan will be training activities on how to cultivate and produce various processed food products made from maja fruit (Aegle marmelos(L) Correa), by presenting resource persons from the Agriculture Service and from the Trade Office to hold guidance for new entrepreneurs in the field of healthy food products.
\end{abstract}

Keywords: Maja Fruit (Aegle marmelos (L)Correa), Stamina, Covid-19

\begin{abstract}
Abstrak. Pandemi Covid-19 menyebabkan masyarakat lebih sadar pentingnya menjaga kesehatan, dalam pola hidupnya lebih memilih untuk kembali ke alam. Tujuan dari Penmas ini sebagai upaya meningkatkan imun/stamina tubuh agar terhindar dari serangan penyakit, termasuk Covid-19. Metode yang digunakan ceramah, tanya-jawab, dan demontrasi. Yang dibahas dalam Penmas ini mengenalkan buah maja (Aegle marmelos (L)Correa) dari berbagai segi baik morfologi, kandungan bahan kimia, potensi, jenis-jenis bioteknologi, teknik dalam bioteknologi, fermentasi, manfaatnya untuk kesehatan dan cara mengemas yang dianjurkan oleh Dinas kesehata. Kesimpulannya: menambah wawasan peserta tentang pentingnya mengenal lebih dalam, akan keberadaan buah maja (Aegle marmelos(L)Correa). Peserta mengetahui cara membuat minuman kesehatan yang higainis berbahan dasar dari buah maja (Aegle marmelos(L)Correa). Menambah pengetahuan peserta cara mengkemas olahan minuman dengan menggunakan kemasan botol plastik.Rencana tahap berikutnya akan diadakan kegiatan palatihan cara budidaya dan memproduksi bermacam produk olahan pangan berbahan dasar dari buah maja (Aegle marmelos(L)Correa), dengan menghadirkan narasumber dari Dinas Pertanian dan dari Dinas Perdagangan untuk mengadakan binaan bagi wirausaha baru di bidang produk pangan yang sehat.
\end{abstract}

Kata Kunci: Buah Maja (Aegle marmelos (L)Correa), Stamina, Covid-19

How to Cite: Sukian Wilujeng, S., Kristianto, S., \& Isrianto, P. L. (2022). Pemanfaatan Tanaman Maja (Aegle marmelos (L.) Correa) Sebagai Upaya Meningkatkan Stamina Pada Masa Pandemi Covid-19 Di Desa Mulyoagung, Dau, Malang. Mitra Mahajana: Jurnal Pengabdian Masyarakat, 3(1), 80-88. doi: https://doi.org/10.37478/mahajana.v3i1.1509

\section{PENDAHULUAN}

Keberadaan Covid-19 berawal dari kasus pneumonia virus yang terjadi di kota Wulan, Provinsi Hubei-Cina (Kemenkes RI, 2020). Pandemi virus corona baru di Indonesia tampaknya belum akan usai dalam waktu dekat. Pasalnya, jumlah kasus positif Covid-19 masih terus bertambah setiap harinya. Dengan kondisi tersebut, menjaga kesehatan dan meningkatkan stamina / imun tubuh di masa pandemi merupakan cara yang cukup bijak agar tidak tertular Covid-19. Pandemi Covid-19 membuat sebagian besar masyarakat lebih sadar pentingnya menjaga kesehatan.

Saat ini masyarakat Indonesia dalam pola hidupnya lebih memilih untuk back to nature seperti halnya makanan, minuman, bahkan obat-obatan. Untuk pengobatan, masyarakat sudah mulai melirik kembali bahan-bahan dari alam yang disebut Herbal Medicine. Banyak yang lebih memilih obat herbal karena tidak mempunyai efek samping untuk jangka pendek maupun 
jangka panjang, dan memiliki beberapa keunggulan seperti toksisitas rendah dan efek samping yang ditimbulkan ringan (M. Atmojo and A. Darumurti, 2021). Dibandingkan dengan obatobatan yang dari bahan kimia.

Mengkonsumsi obat herbal salah satunya dari tanaman maja (Aegle marmelos (L.) Correa) merupakan upaya untuk meningkatkan stamina tubuh agar terhindar dari serangan penyakit, termasuk Covid-19. "Konsumsi herbal yang aman, bermanfaat, higienis dan baik untuk tubuh, menjadi salah satu upaya preventif yang perlu dibudayakan oleh masyarakat pada masa pandemi ini," imbauan Kepala Badan POM RI, Penny K. Lukito dalam Focus Group Discussion (FGD) virtual "Peran Herbal dan Suplemen Kesehatan Menghadapi Pandemi COVID-19" di Kantor Badan POM, Kamis (14/05/2020).

Status tanaman maja di Banglore, India masuk kategori spesies yang Rare, Endangered and Threatened (RET) dalam The Foundation for Revitalization of Local Health Traditions (FRLHT) (Venudevan dan Srimathi,, 2014). Neeraj et al., 2017 menyatakan dalam penelitiannya bahwa Aegle marmelos L. dianggap sebagai tanaman bernutrisi atau tanaman obat-obatan. Tanaman ini merupakan salah satu tanaman buah yang paling diabaikan dan kurang dimanfaatkan.Buah maja (Aegle marmelos (L.) Correa) mengandung tanin sebesar 9\% yang terdapat pada daging buah dan 20\% pada kulit buah (Chavda et al., 2012).

Buah Maja (Aegle marmelos) merupakan salah satu jenis tumbuhan yang dianggap cukup unik di kalangan masyarakat Indonesia. Kata Majapahit itu sendiri berasal dari dua kata, yaitu : Maja dan Pahit yang artinya buah Maja yang rasanya pahit, (Abdullah, 2018) Buah maja sekarang mulai banyak dicari untuk pengobatan. Buah maja juga masih jarang dimanfaatkan oleh masyarakat sekitar, dikarenakan buah maja tidak bisa dikonsumsi. Tetapi buah Maja sendiri menyimpan banyak manfaat untuk kesehatan.

Dilatar belakangi adanya himbauan menjaga kesehatan dengan memanfaatkan bahan dari herbal, maka tim Pengabdian Kepada Masyarakat dari Jurusan Biologi, Fakultas Bahasa dan Sains, Universitas Wijaya Kusuma Surabaya. Tergugah memberikan pelatihan pada ibu-ibu PKK Desa Mulyo Agung, Kecamatan Dau, Kabupaten Malang, dengan alasan daerah tersebut berdekatan dengan tanam rekreasi Sengkaling yang sering didatangi oleh pengunjung dari luar daerah. Oleh karena itu perlu menjaga imun untuk memenfaatkan salah satunya tanaman maja (Aegle marmelos (L.) Correa) sebagai upaya meningkatkan stamina / imun tubuh agar terhindar dari serangan penyakit, termasuk Covid-19.

\section{METODE PELAKSANAAN}

Metode kegiatan Pengabdian Kepada Masyarakat ini dilakukan melalui kegiatan pelatihan kepada ibu-ibu PPK Desa Mulyo Agunng, Kecamatan Dau, Kabupaten Malang tentang bagaimana membuat minuman hasil dari fermentasi tanaman buah Maja (Aegle marmelos (L.) Correa). Adapun proses pelaksanaan program ini adalah melalui tahap-tahap sebagai berikut:

1. Tahap Persiapan yang dilakukan meliputi :

a. Survey lokasi pengabdian kepada masyarakat

b. Pemantapan dan penentuan lokasi dan sasaran

c. Penyusunan bahan/materi pelatihan, yang meliputi: pembuatan makalah, penyiapan bahan dan alat

\section{Tahap Pelaksanaan Pelatihan}

Kapan pelaksanaan pelatihan merupakan hasil kesepakatan antara tim Pengabdian Kepada Masyarakat, Program Studi Pendidikan Biologi dengan para peserta pelatihan. Pelatihan ini diberi judul "Pemaanfaatan Tanaman Maja (Aegle Marmelos (L.) Correa) Sebagai Upaya Meningkatkan Stamina Pada Masa Pandemi Covid-19 Di Desa Mulyo Agung, Kec. Dau, Kab. Malang". Dengan adanya pelatihan ini tim Pengabdian Kepada Masyarakat, Program Studi Pendidikan Biologi, berharap dapat meningkatkan pengetahuan para peserta tentang manfaat 
buah maja (Aegle Marmelos (L.) Correa), sekaligus bila para peserta mengimplementasikan hasil mengikuti pelatihan bisa menambah pendapatannya karena masih mempunyai peluang yang tinggi dari segi pemasarannya

a. Pembukaan diawali oleh bacaan salam oleh MC

b. Pemateri pertama sosialisasi dengan metode cerama tentang morfologi dari tanaman buah maja (Aegle Marmelos (L.) Correa), kandungan bahan kimia buah maja (Aegle Marmelos (L.) Correa), potensi buah maja (Aegle Marmelos (L.) Correa), bioteknologi, jenis-jenis bioteknologi, teknik-teknik dalam bioteknologi, fermentasi buah maja (Aegle Marmelos (L.) Correa), proses bioteknologi secara alam dan beberapa maanfaat dari buah maja (Aegle Marmelos (L.) Correa) untuk kesehat

c. Pemateri kedua menggunakan metode pelatihan dengan menunjukkan kepada para peserta cara memilih buah maja (Aegle Marmelos (L.) Correa) yang sudah tua, sehingga nantinya dalam proses fermentasi hasilnya terasa manis. Setelah sari buah didapatkan, dilanjutkan dengan teknik perebusan supaya didapatkan sari yang higeinis untuk kesehatan, setelah dingin baru tahap akhir pengemasan dengan menggunakan jenis botol yang dianjurkan oleh Dinas Kesehatan. Dalam pelatihan ini dijelaskan pula model-model kemasan yang lebih manarik dan modern sehingga menarik minat orang apabila dijual nantiknya (CV.D\&D. Indonesia, 2013)

d. Sesi berikutnya tanya jawab

e. Penutupan diakhiri dengan bacaan Basmallah

3. Metode Yang Digunakan

a. Metode Ceramah

b. Metode Pelatihan

c. Metode Tanya Jawab

Metode-metode ini dianggap oleh tim Pengabdian Kepada Masyarakat, sebagai metode yang mudah dan tepat dalam pelatihan "Pemaanfaatan Tanaman Maja (Aegle Marmelos (L.) Correa) Sebagai Upaya Meningkatkan Stamina Pada Masa PandemiCovid-19 Di Desa Mulyo Agung, Kec. Dau, Kab. Malang" ini.

\section{HASIL DAN PEMBAHASAN}

Buah maja (Aegle marmelos (L.) Correa) selain mengandung marmelosin juga minyak atsiri, pektin, vitamin c dan tannin, (Rismayani, 2013). Buah maja (Aegle marmelos (L.) Correa) bentuknya bulat dengan diameter 5-12 cm, kulit luarnya berwarna hijau dan bertekstur keras (Batutah, 2017), satu pohon mampu menghasilkan buah 200-300 biji(Rismayani, 2013).

Tanin terdiri dari sekelompok zat-zat kompleks terdapat secara meluas dalam tumbuhtumbuhan, antara lain terdapat pada bagian kulit kayu, batang, daun, dan buah-buahan. Tannin juga dinamakan asam tanat dan asam galotanat, ada yang tidak berwarna tetapi ada juga yang berwarna kuning atau cokelat. Buah Maja mengandung tanin sebesar 9\% yang terdapat pada daging buah dan 20\% pada kulit buah(Chavda et al., 2012). Rasa pahit pada buah Maja ketika belum masak disebabkan oleh kandungan tannin yang terdapat di dalamnya.Tannin adalah metabolit sekunder tanaman yang bersifat astrigen dengan rasa khas yang sepat. Kandungan tannin dalam buah Maja akan hilang apabila sudah masak. Buah maja yang sudah masak dapat dikonsumsi dikarenakan dapat diolah menjadi sorbet, selai, sirup, dan nektar. Tanin sangat bermanfaat untuk tanaman itu sendiri dan manusia

Minyak atsiri atau yang dikenal sebagai minyak eteris (aetheric oil), minyak esensial, minyak terbang serta minyak aromatik adalah kelompok besar minyak yang berasal dari tumbuh-tumbuhan yang merupakan bahan dasar dari wangi-wangian atau minyak gosok 
(untuk pengobatan) alami dan mempunyai aroma khas. Dalam perdagangan minyak atsiri dikenal sebagai bibit minyak wangi(Republika., 2017).

Wujud pektin yang diekstrak adalah bubuk putih hingga coklat terang. Fungsi utamanya sebagai bahan pengental dan pembentuk gel. Pada industri makanan pektin digunakan sebagai bahan pembentuk gel (gelling agent), pengental, dan stabilizer pada berbagai produk seperti selai, jeli, produk-produk susu, permen, produk buah- buahan kemasan, juice, dan es krim sebagai penstabil. Disamping untuk memperbaiki tekstur makanan olahan, pektin juga mempunyai peranan penting dalam menurunkan kadar kolesterol total (Rahayu, 2017).

Vitamin $\mathrm{C}$ adalah salah satu jenis vitamin yang larut dalam air dan memiliki peranan penting dalam menangkal berbagai penyakit. Vitamin ini juga dikenal dengan nama kimia dari bentuk utamanya yaitu asam askorbat. Vitamin $C$ termasuk golongan vitamin antioksidan yang mampu menangkal berbagai radikal bebas ekstraselular (Agestina, 2013).

Selain itu buah Maja juga berpotensi sebagai uji efektivitas antara buah Maja muda dan buah Maja tua sebagai bahan pembersih logam besi (Fatmawati, 2015). Buah Maja juga mempunyai potensi sebagai uji insektisida nabati terhadap hama walang sangit, dengan konsentrasi $40 \%$ dengan menggunakan metode semprot serangga dapat mematikan $50 \%$ hama walang sangit (Rahel et al, 2017).

Tabel 1. Kandungan Buah Maja (Aegle marmelos (L.) Correa)(Rismayani, 2013)

\begin{tabular}{lll}
\hline Kadungan & & Kadar/100 gram \\
\hline Air & $:$ & $61,5 \mathrm{gr}$ \\
Protein & $:$ & $1,8 \mathrm{gr}$ \\
Lemak & $:$ & $0,39 \mathrm{gr}$ \\
Karbohidrat & $:$ & $31,8 \mathrm{gr}$ \\
Abu & $:$ & $55 \mathrm{gr}$ \\
Karotena & $:$ & $0,13 \mathrm{mg}$ \\
Tiamin & $:$ & $1,19 \mathrm{mg}$ \\
Riboflavin & $:$ & $1,1 \mathrm{mg}$ \\
Niasin & $:$ & $3 \mathrm{mg}$ \\
Vitamin C &
\end{tabular}

a. Hasil Kegiatan Penmas

Program Pengabdian Kepada Masyarakat dengan judul "Pemaanfaatan Tanaman Maja (Aegle Marmelos (L.) Correa) Sebagai Upaya Meningkatkan Stamina Pada Masa PandemiCovid19 Di Desa Mulyo Agung, Kec. Dau, Kab. Malang" telah berjalan dengan baik. Pelatihan diikuti oleh 20 peserta, dan dilaksanakan pada tanggal 23 Januari 2021. Kegiatan pelatihan diawali dengan pembukaan salam oleh MC sekaligus membacakan susunan acara. Acara pertama pemberian materi, dilanjutkan dengan acara ke dua pelatihan pembuatan minuman kesehatan dari buah Maja (Aegle Marmelos (L.) Correa), acara yang ke tiga seksi tanya jawab dan ditutup bacaan alhamdulilah.

Pemateri berasal dari tim dosen Pengabdian Kepada Masyarakat, Program pendidikan Biologi, Fakultas Bahasa dan Sain, Universitas Wijaya Kusuma Surabaya. Menyampaikan materi cara pembuatan minuman kesehatan dari buah Maja (Aegle Marmelos (L.) Correa). Sedangkan kegiatan pelatihan diawali demotrasi yang diperagakan oleh salah satu dosen. Untuk selanjutnya peserta pelatihan bergantian mempraktekkan cara membuat minuman kesehatan dari buah Maja (Aegle Marmelos (L.) Correa), sambil dilaksanakan seksi tanya jawab.

Setelah dilaksanakannya pelatihan, hasil yang didapatkan ialah: (1) Meningkatnya keinginan peserta untuk membuat minuman kesehatan dari buah Maja (Aegle Marmelos (L.) Correa); (2) Meningkatnya keinginan untuk hidup sehat dengan memanfaatkan bahan yang alami; (3) Menambah pengetahuan peserta tentang maanfaat buah Maja (Aegle Marmelos (L.) Correa) untuk meningkatkan stamina pada masa pandemi covid-19; (4) Merubah pandangan peserta 
tentang buah Maja (Aegle Marmelos (L.) Correa) yang mempunyai rasa pait dan tidak dapat dimanfatkan.

\section{b. Pembahasan Hasil Pelaksanaan Kegiatan Penmas}

Program Pengabdian Kepada Masyarakat dengan judul "Pemaanfaatan Tanaman Maja (Aegle Marmelos (L.) Correa) Sebagai Upaya Meningkatkan Stamina Pada Masa PandemiCovid19 Di Desa Mulyo Agung, Kec. Dau, Kab. Malang" telah berjalan dengan baik. Pelatihan diikuti oleh 20 peserta, dan dilaksanakan pada tanggal 23 Januari 2021. Kegiatan pelatihan diawali dengan pembukaan salam oleh MC sekaligus membacakan susunan acara. Acara pertama pemberian materi, dilanjutkan dengan acara ke dua pelatihan pembuatan minuman kesehatan dari buah Maja (Aegle Marmelos (L.) Correa), acara yang ke tiga seksi tanya jawab dan ditutup bacaan alhamdulilah.

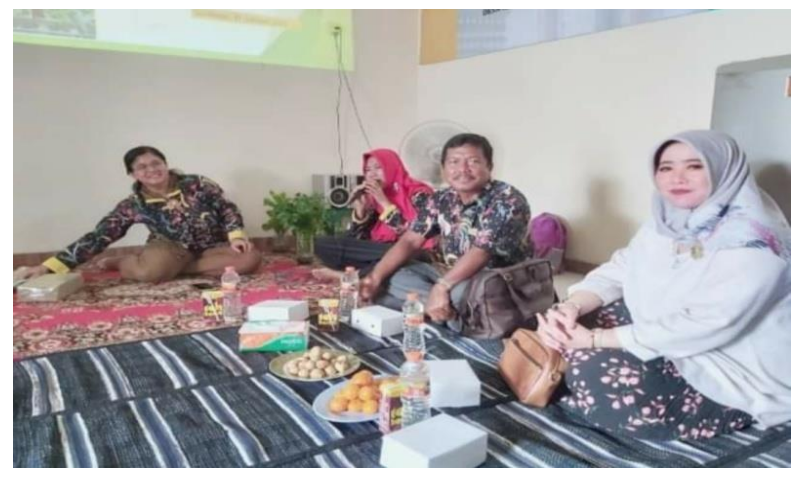

Gambar 1. Pembukaan Pelatihan

Materi yang disampaikan pada pelatihan ini ialah informasi tentang morfologi dari tanaman buah maja (Aegle Marmelos (L.) Correa), kandungan bahan kimia buah maja (Aegle Marmelos (L.) Correa), potensi buah maja (Aegle Marmelos (L.) Correa), bioteknologi, jenis-jenis bioteknologi, teknik-teknik dalam bioteknologi, fermentasi buah maja (Aegle Marmelos (L.) Correa), proses bioteknologi secara alam dan beberapa maanfaat dari buah maja (Aegle Marmelos (L.) Correa) untuk kesehatan

Materi tersebut disampaikan oleh Dr.Ir. Sukian Wilujeng,MM. Pemateri merupakan salah satu wirausaha dan dosen di Jurusan Pendidikan Biologi sekaligus sebagai Ketua Program Studi yang sedang melaksanakan penelitihan buah maja (Aegle Marmelos (L.) Correa) sehingga relevan dengan materi yang disampaikan.

Buah maja (Aegle Marmelos (L.) Correa) banyak tumbuh di Daerah Mojokerto, di mata masyarakat Jawa Timur banyak dikaitkan dengan keberadaan Kerajaan Mojopait yang letaknya di Kota Mojokerto, sehingga masyarakat beranggapan sebutan buah maja (Aegle Marmelos (L.) Correa) yang rasanya pait. Memang buah maja (Aegle Marmelos (L.) Correa) kalau masih mudah bila dimarasakan terasa pait, tetapi buah maja (Aegle Marmelos (L.) Correa) yang sudah tua terasa manis.

Buah maja (Aegle Marmelos (L.) Correa) selama ini belum banyak orang yang mengenal. Keberadaan buah maja (Aegle Marmelos (L.) Correa) biasanya tumbuh liar di pemakaman, belum ada yang membudidayakan secara komersial dikarenakan buah maja (Aegle Marmelos (L.) Correa) tidak bisa dikonsumsi.

Melalui pelatihan ini memberikan informasi ke pada peserta ternyata buah maja (Aegle Marmelos (L.) Correa) menyimpan banyak manfaat untuk kesehatan. Beberapa hasil penelitian menyatakan buah maja (Aegle Marmelos (L.) Correa) juga digunakan sebagai bahan olahan menjadi minuman tradisional bernama "sharbat", terbuat dari daging buah maja yang dihaluskan, di campur air, gula atau sirup dan es. Sayuran popular dari buah maja adalah bagian pucuk maja. Terdapat dalam ilmu pengobatan tradisional di India (Ayurvedic), maja digunakan 
sebagai obat gangguan pencernaan dan obat penurun demam pada bagian akarnya (Rismayani, 2013).

Menurut Merapi (2018) menyatakan bahwa selembar daun maja yang telah dicuci bersih dan dihaluskan hingga menjadi jus dengan penambahan madu asli secukupnya dapat berguna untuk melawan penderita hipertensi. Untuk melawan rasa mual dan muntah dapat memanfaatkan bagian buah maja yang masih mentah dan segar. Buah maja yang telah dikeringkan tanpa biji dan digiling menjadi bubuk dapat digunakan sebagai penghambat diare.

Menginjak pada acara yang ke dua yaitu pelatihan pembuatan minuman kesehatan dari buah Maja (Aegle Marmelos (L.) Correa) yang dibimbing oleh ibu Pramita Laksitarahmi I,S. Si.,M.Si. Beliau juga salah satu dosen di Jurusan Pendidikan Biologi, yang berkopenten dibidangnya terutama pada bidang penelitian, sehingga relevan bila sebagai pembimbing dalam pelatihan ini.

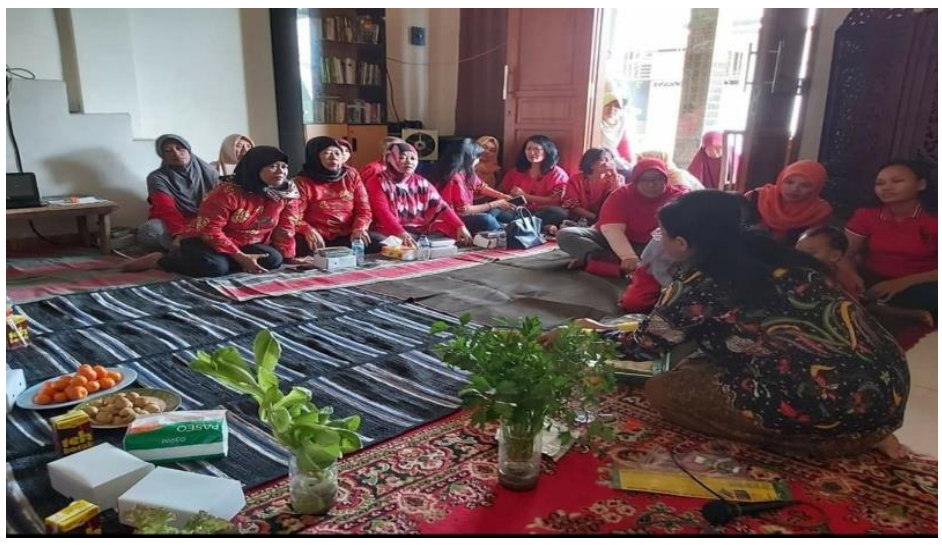

Gambar 2. Demo Pembuatan Minuman

Pada pelatihan ini ditunjukkan kepada para peserta cara memilih buah maja (Aegle Marmelos (L.) Correa) yang sudah tua, sehingga nantinya dalam proses fermentasi hasilnya bagus. Proses fermentasi merupakan kegiatan mikrobia pada bahan pangan sehingga dihasilkan produk yang dikehendaki. Secara umum, fermentasi adalah salah satu bentuk respirasi anaerobik, akan tetapi, terdapat definisi yang lebih jelas yang mendefinisikan fermentasi sebagai respirasi dalam lingkungan anaerobik dengan tanpa akseptor elektron eksternal. Seiring dengan perkembangan teknologi, definisi fermentasi meluas menjadi semua proses yang melibatkan mikroorganisme untuk menghasilkan suatu produk yang merupakan metabolit primer atau sekunder dalam suatu lingkungan yang dikendalikan.

Fermentasi yang dilakukan pada pembuatan minuman kesehatan kali ini, menggunakan salah satu bioteknologi konvensional yang sangat sederhana yaitu menunggu proses alami yang terjadi pada buah maja (Aegle Marmelos (L.) Correa) itu sendiri, yang membutuhan waktu kurang lebih 2-3 minggu tergantung dari tingkat kematangan buah itu sendiri. Metode ini telah lama dipakai pada produk pangan karena murah dan baik untuk mengawetkan bahan makanan dengan memanfaatkan pertumbuhan mikroflora alami pada bahan menghasilkan asam laktat, asam asetat, etanol, enzim, bakteriosin, dan aroma khas. Bakteri asam laktat dapat merombak gula menjadi asam laktat serta menghasilkan enzim amilolitik yang dapat membuat senyawa menjadi lebih sederhana(Yuliana, et al, 2014).

Proses selanjutnya buah dibelah dengan menggunakan pisau besar karena kulitnya keras, untuk mendapatkan sari dari buah maja (Aegle Marmelos (L.) Correa) tersebut. Setelah sari buah didapatkan, dilanjutkan dengan teknik perebusan sederhana dengan menggunakan kompor LPJ, tujuannya untuk menghasilkan sari buah maja (Aegle Marmelos (L.) Correa) yang higeinis sehingga baik untuk kesehatan setelah meminumnya, tahap akhir dari proses pembuatan minuman buah maja (Aegle Marmelos (L.) Correa) ini dengan mengemasnya sesuai dengan yang dikehendaki oleh peserta, tetapi pada pelatihan ini digunakan kemasan dari botol plastik yang sudah disediakan. 


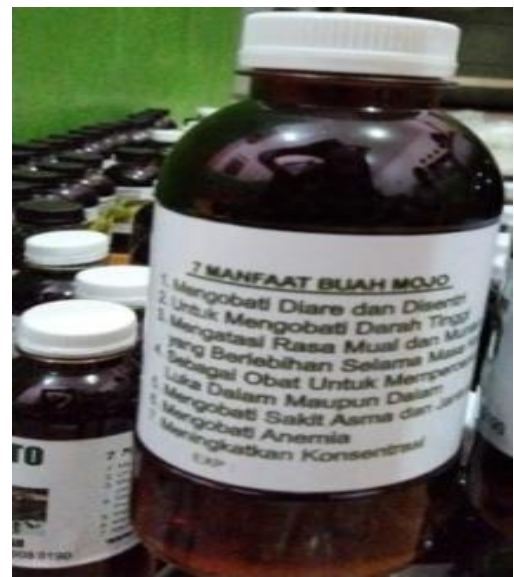

Gambar 3. Botol Kemasan Minuman

Pada sesi tanya jawab peseta sangat antusias menyaikan pertanyaan kepada baik ke pemateri maupun pembimbingan pelatihan, salah satu pertanyaannya adalah bagaimana kalau salah memilih buah, karena tidak mengetahui dari tingkat kematangannya. Jawabnya nantinya akan berpengaruh kepada rasa yaitu agak terasa asam. Lama fermentasi merupakan salah satu faktor yang mempengaruhi kualitas fisik yang terfermentasi. Semakin lama proses fermentasi, aktivitas mikroba dalam merombak pati semakin besar sehingga meningkatkan viskositas dan tingkat kelarutan. Namun semakin lama fermentasi juga akan menyebabkan penurunan aroma dan citarasa (Anggraeni dan Yuwono, 2014).

Pertanyaan berikutnya pada tahap perebusan "sebaiknya pada waktu merebus menggunakan bahan dari apa yang bagus untuk kesehatan. Jawabpannya dari stainless stell biar tidak terjadi kontaminasi bila memakai bahan perebusan dari panci biasa.

Pada tahap pengemasan timbul pertanyaan pada peserta, sebaiknya dalam memilih kemasan bagaimana kemasan yang baik untuk kesehatan, kemasan selain mempengaruhi estetika dalam nilai jual, yang terpenting dari segi kesehatan memilih kemasan yang dianjurkan dari Dinas Kesehatan. Contohnya bila memilih kemasan dari botol plastik pilihlah botol plastik yang mempunyai kwalitas yang terbaik yang bahannya ramah lingkungan, karena sampah platik baru akan hancur dalam waktu 200-400 tahun (Yohana, 2017). Ditunjang juga oleh penelitihannya (Karuniastuti, 2013) bahwa sampah plastik membutuhkan ratusan tahun baru dapat terurai dengan sempurna oleh tanah.

Berdasarkan pengamatan selama berlangsungnya acara pelatihan ini, bisa dikatakan bahwa acara tersebut mendapatkan respon yang positif dari para peserta. Hal ini dapat dilihat dari antusias peserta yang mengikuti pelatihan secara aktif dan berjalan dengan lancar. Demi untuk memberi dorongan supaya peseta mempraktekkan dari hasil pelatihaannya dengan benar, pihak pebimbing memberikan bimbingan lewat whatsapp grup antara dosen dan para peserta pelatihan.

Kendala dalam pelatihan ini berupa susahnya untuk mendapatkan buah maja (Aegle Marmelos (L.) Correa), karena belum dibudidayakan secara massal. Buah maja (Aegle Marmelos (L.) Correa) hanya ada satu atau dua pohon saja yang tumbuh di halaman pekarangan rumah itupun jarang ditemui. Buah maja(Aegle Marmelos (L.) Correa) mempunyai bentuk buah yang bagus dan menarik sebagai tanaman hias. Buah maja (Aegle Marmelos (L.) Correa) banyak tumbuh di area pemakaman, biasanya oleh anak-anak dipakai mainam sepak bolah bila sudah jatuh dan kering warnanya beruba menjadi coklat dan beratnya sangat ringan.

Harapan dari Tim Pengabdian Kepada Masyarakat, Program Studi Pendidikan Biologi, untuk para peserta setelah diberi pelatihan bisa merubah dari sudut pandangan terhadap adanya buah maja (Aegle Marmelos (L.) Correa) yang dulunya tidak dimanfaatkan sekarang 
dijadikan sarana untuk hidup sehat. Karena masyarakat sekarang memilih pola hidup back to nature untuk pengobatan, masyarakat sudah mulai melirik kembali bahan-bahan dari alam yang disebut Herbal Medicine. Banyak yang lebih memilih obat herbal karena tidak mempunyai efek samping untuk jangka pendek maupun jangka panjang, dibandingkan dengan obat- obatan bahan kimia. Data (Badan Penelitian dan Pengembangan Kesehatan, 2014) menunjukkan bahwa $50 \%$ penduduk Indonesia menggunakan herbal/jamu baik untuk menjaga kesehatan maupun untuk pengobatan karena sakit.

\section{SIMPULAN DAN TINDAK LANJUT}

Simpulan akhir dari pelaksanaan Pengabdian Kepada Masyarakat dengan judul "Pemaanfaatan Tanaman Maja (Aegle Marmelos (L.) Correa) Sebagai upaya meningkatkan Stamina Pada Masa PandemiCovid-19 Di Desa Mulyo Agung, Kec. Dau, Kab. Malang” ialah:

1. Menambah wawasan peserta tentang pentingnya mengenal lebih dalam, akan keberadaan buah maja (Aegle marmelos(L)Correa).

2. Peserta mengetahui cara membuat minuman kesehatan yang higainis berbahan dasar dari buah maja (Aegle marmelos(L)Correa).

3. Menambah pengetahuan peserta cara mengkemas olahan minuman dengan menggunakan kemasan botol plastik.

Rencana tahap berikutnya akan diadakan kegiatan palatihan cara budidaya dan memproduksi bermacam produk olahan pangan berbahan dasar dari buah maja (Aegle marmelos(L)Correa), dengan menghadirkan narasumber dari Dinas Pertanian dan dari Dinas Perdagangan untuk mengadakan binaan bagi wirausaha baru di bidang produk pangan yang sehat.

Alasan untuk membudidayakan dan membuat produk olahan pangan dari bahan dasar buah maja (Aegle marmelos(L)Correa), karena setiap bagian tubuh tanaman mengandung senyawa aktif berupa antioksidan yang mampu dimanfaatkan dalam mendukung mekanisme perbaikan sel tubuh makhluk hidup. Buah maja (Aegle marmelos(L)Correa), mengandung zat aktif berupa choline yang berguna untuk meningkatkan mekanisme perbaikan dalam sel neuron otak sehingga berpotensi untuk meningkatkan kecerdasan. Choline tersebut tidak hanya terkandung dalam buah yang segar, melainkan juga terkandung pada berbagai bentuk bahan olahannya.

\section{DAFTAR PUSTAKA}

Abdullah, T. (2018). Buah Maja Pengispirasi Majapahit. https://www.cendananews.com/2018/06/inilah-buah-penginspirasi-majapahit.html

Agestina, E. D. (2013). Kadar Vitamin C Dan Glukosa Pada Yoghurt Siwalan (Borassus flabellifer Linn) Dengan Konsentrasi Starter Dan Lama Fermentasi Yang Berbeda.

Anggraeni, Y. P., dan Yuwono, S. S. (2014). Pengaruh fermentasi alami pada chips ubi jalar (Ipomoeabatatas) terhadap sifat fisik tepung ubi jalar terfermentasi. Jurnal Pangan Dan Agroindustri, 2(2), 59-69.

Badan Penelitian dan Pengembangan Kesehatan. (2014). Riset Saintifikasi Jamu. Kementerian Kesehatan RI. www.litbang.depkes.go.id

Batutah, M. . (2017). Distilasi Bertingkat Bioetanol dari Buah Maja (Aegle marmelos L.). Jurnal IPTEK, 21(2).

Chavda N., Mujapara A., M. S. . and D. P. . (2012). Primary Identification of Certain Phytochemical Constituents of Aegle Marmelos (L.) Corr. Serr Responsible for Antimicrobial Acticity Againts Selected Vegetable and Clinical Phatogen. International Journal of Physical and Social Sciences, 2(6), 194. www.ijmra.us

CV.D\&D. Indonesia. (2013). Model-model Kemasan. www kemasanUKM.com. 
Fatmawati. (2015). Efektivitas Buah Maja (Aegle marmelos (L.) Corr.) Sebagai Bahan Pembersih Logam Besi. Jurnal Konservasi Cagar Budaya Borobudur, 9(1), 81-87.

Kemenkes RI. (2020). Pedoman Pencegahan dan Pengendalian Coronavirus Disease (Covid-19),.

M. Atmojo and A. Darumurti. (2021). Pemberdayaan Masyarakat Melalui Tanaman Obat Keluarga (TOGA). J. Abdimas BSIJ. Pengabdi. Kpd. Masy, 4(1), 100-109.

Merapi, H. (2018). Maja Bantu Lawan Hipertensi. https://www.harianmerapi.com/herbal/2018/01/18/5877/maja-bantulawanhipertensi

Neeraj., Bisht, V., and V. J. (2017). Bael (Aegle marmelos) Extraordinary Species of India: A Review, International. Journal of Basic \& Applied Sciences, 6(3), 1870-1887.

Rahayu, S. (2017). Pektin dan Manfaatnya. http://eprints.polsri.ac.id/5160/pdf

Rahel, D., A. Wibowo, I. M. Y. (2017). Efektifitas Ekstrak Buah Maja (Aegle marmelos) Terhadap Mortalitas Walang Sangit (Leptocorisa acuta) Pada Tanaman Padi.

Republika. (2017). Manfaat Minyak Atsiri.

Rismayani. (2013). Manfaat Buah Maja sebagai Peptisida Nabati untuk Hama Penggerek Buah Kakao (Conopomorpha cramerella). Warta Penelitian Dan Pengembangan Tanaman Industri, 19(3).

Venudevan, B dan P, S. (2014). Seed Technological Approaches for Restoration of Endangered Medicinal Tree Bael (Aegle marmelos (L.) Corr.). Life Sciences Leaflets, 54(22), 61-67.

Yohana, C. (2017). Training on Utilization of Plastic Waste and Banana Bark Become an Economical Value Innovation Product. Rnal Pemberdayaan Masyarakat Madani (JPMM), 1(1), 46-47. https://doi.org/10.21009/jpmm.001.1.04

Yuliana, N., Nurdjanah, S., Sugiharto, R., dan Amethy, D. (2014). Effect of spontaneous lactic acid fermentation on psysico-chemical properties of sweet potato flour. Microbiology Indonesia, 8(1), 1-8. 